\title{
Intensity of Informal Competition among Firms in Ethiopia
}

\author{
Abiy Serawitu \\ Dire Dawa Management and Kaizen Institute, Dire Dawa, Ethiopia
}

\begin{abstract}
The study investigated intensity of informal competition among firms in Ethiopia and predicted the level and nature of this competition. The study found that prevalence of highest corruption, tax rates, financial constrained are found to be positively and significantly affecting competition against informal firms in Ethiopia. On the contrary, firm size found to be negatively and significantly affecting competition against informal firms. Similarly, the study revealed that tax regulation and inspection enforcement conducted by tax officials could not save firms from informality. Even if most research indicated that increase in government enforcement on tax code lead to reduce informality, however in this research it is required further study as to how tax code inspections and regulation could not bring negative result on informal competition
\end{abstract}

Keywords: intensity of informal competition, binary probit and econometric model

DOI: $10.7176 /$ RJFA/12-19-01

Publication date:October $31^{\text {st }} 2021$

\section{Introduction}

Competition is an engine of economic growth in most markets since it induces higher rates of productivity growth; however, competition between formal and informal firms is not necessarily lead to productive. Informal competition is harmful to overall economic performance since the cost advantage informal firms enjoy is a result of ignoring many or all business regulations. There are also cost disadvantages to informality. Some of these disadvantages stem from inaccessibility to formal credit markets and to the courts. This makes informal firms less efficient. (Djankov et al, 2003). Formal firms operating in a context where informal firms are widespread are likely to be negatively affected by the operations of informal firms. While sometimes the informal sector itself has been a source of innovations (Radjou et al., 2012). On the other hand, informal producers may affect formal firms' innovation decisions are via competition in the product market. By their very nature, informal firms face lower entry costs than formal firms, since they are less affected by regulatory burdens imposed on formal firms (McKenzie,Seynabou Sakho, 2010)

Being compensate for the lack of legal protection that courts provide, informal firms make deals that are small to minimize possible losses and they make these deals with parties where there are long-established relations. Small contracts, however, usually involve high fixed costs. Also, limiting transactions to parties with whom informal firms have long-established relations means that informal firms exploit only a small and narrow set of market opportunities. Inefficiencies and limited markets is the price of reducing uncertainty and insuring against losses in the informal sector.

Even though most of studies showed theoretically and empirically the negative impacts of the informal sector on the overall economy, its size is however, continues to grow very fast in developing countries (ElHamidi 2011). The business environment substances in determining the nature and size of the cost advantages of informality. The higher the regulatory burdens of being formal, the higher are an savings from informality. This cost-benefit calculation affects the size of the informal sector as higher savings from being informal draws more firms to informality, resulting in a bigger informal sector (Djankov et al 2002). While the size of the informal sector is a vital factor in determining the competitive effects on formal firms more in a market generally means more price competition regulation is most importantly a major determinant of the intensity of competition from the informal sector.

The government's capacity to enforce regulations also matters in the evaluation of the cost of regulatory obligations firms face. An informal firm's chances of getting caught for not complying with laws and regulations are a direct function of the government's capacity to enforce these. The two points above on the determinants of the size and intensity of informal competition are the central focus of this paper.

\subsection{Statement of the Problem}

Several definitions of informal firms have been obtainable by different studies; these studies rely on Nichter and Gold mark (200) who defines informal firms as "businesses that are unregistered but derive income from the production of legal goods and services." One distinguished clarification revealed is the recent study of Iriyama et al. (2016). The study exhibited that informal firms are able to operate more quickly by avoiding regulations and more cheaply by avoiding taxes and fees. When facing these informal competitors, formal firms respond by engaging in corruption payoffs to regulatory officials in order to follow informal firms to try to achieve equality on speed and low cost. 
In assessing the determinants of informal activity, informal firms are most common in countries where the legal, economic, and regulatory systems are such that it is costly and procedurally challenging to register firms and operate in the realm of law (Godfrey, 2011). For instance, higher tax rates, corruption, extortion, and high cost-benefit of achiving output have been shown to positively influence the extent of hidden business activity and informal activity (Johnson et al., 2000; Schneider and Enste, 2002; de Soto, 2000).

Informal competition from informal firm's remains relatively less studied and underexplored in developing countries. Iriyama, Kishore and Talukdar(2016) on their recent study endeavored to address this gap by founding potential competitive advantages of informal firms, including the ability to operate more quickly and at lower costs by avoiding regulations. The study also argued that one way formal firms can respond is to engage in corrupt activities such as payoffs to regulatory officials in an attempt to achieve parity on speed and low cost. Generally, the extant of literatures in different country levels have informed the determinants and intensity of informal completion in an economy; however, the intensity of informal completion among firms in Ethiopia has remained relatively less surveyed. Yet, this paper tries to fill this gap by analyzing. Primary data source of 2015 World Bank Enterprise Surveys for Ethiopia.

\subsection{Objectives of the Study}

The objective of this study is to investigate intensity of completion against informal firms and identify the associated factors.

Hypothesis 1: Size of firms are not significantly and negatively related to competition against informal firms Hypothesis 2: Experience of top manager is not significantly and negatively related to competition against informal firms (informal competition).

\section{Literature Review}

Gonzalez and Lamina (2007) examined the characteristics of formal firms subject to the practices of competitors in the informal sector in 14 Latin American countries in 2006. Using a probit regression model, the study assumed that formal and informal firms compete with each other and are not in segmented or separated markets as suggested by the dual economic theory. The study revealed that formal firms most resembling informal ones are the ones most adversely affected by informal competition. These formal firms are usually small, credit constrained firms, operating in industries with low entry costs and serving the same kind of consumers as informal firms. They also concluded that informal competition is a threat, especially in countries with low government capacity and highly regulated.

Friesen and Wacker (2013) investigated the relationship between formal firms' access to finance and informal competition in 114 developing and transition countries over the period 2006 to 2011.Using their analysis on the results of Gonzalez and Lamanna (2007) by assuming that the existence of informal competition threatens the operations of formal firms. Using a nonlinear ordered response model, the study found that the more financially constrained formal firms are, the more they are subject to competition from the informal sector. They concluded that the financial constraint is the first determinant of informal competition's severity. This in turn is also affected by other variables, such as corruption, labor regulation and firm size.

Taking into consideration the fact that informality is the main force of productivity gap between developed and developing countries, Hendy and Zaki (2013) found that the probability of belonging to the informal sector is a function of firm age, entrepreneur gender, age and education. Using dataset on micro and small enterprise in Egypt and Turkey, the study also concluded that the productivity differential between formal and informal firms in Egypt is not significant comparing to the Turkish case.

Ali (2014) focused the multiplier effect associated with informality: once a firm joins the informal sector, the social stigma associated to operate informally and to break rules decreases. Then, more firms and persons are encouraged to join this informal sector. The considerate of this vicious cycle is subject to the quality of the regulatory environment and institution. The complexity in the entrance of new firm in terms of tax rates, regulatory burdens and access to finance encourages firms to join the informal sector. As highlighted by De Soto (1990), informal enterprises are a consequence of government bureaucracy. As a result, participants in the informal sector in Egypt might choose to remain informal not only to avoid taxes and regulation but also due to the inability of the government to enforce law and regulation (Charmes, 2000).

Gonzalez and Lamanna (2007) conducted a study entitled who fears competition from informal firms? Evidence from Latin America with the 2006 World Bank Enterprise Surveys for Latin America using probit model .The study used firm size ,capacity utilization , number of buyers, export ,financial dependence ,tax rate ,government capacity, corruption , access to formal finance are found to be the determinants of informal competition

McCann and Bahl (2017) investigated the influence of competition from informal firms on new product development. Using logistic regression and development of new product as dependent binary variable .The study used irregular payment prevalence, regulatory hopefulness, firm age and firm size as an expiatory variable. 
Iriyama et al.(2016) studied the threat from informal competitors was largely associated with cost or speed advantages from avoiding entanglements with regulatory institutions. Whether this threat merits response by the focal firms depends on how much of an advantage the focal firms perceives has been gained by informal competitors. When focal firms' managers are negative about the strength of the regulatory environment, they are likely to perceive the advantage gained by the avoidance activities of informal firms to be more significant. In contrast, optimism about the regulatory environment is associated with perceptions of less consequential

\section{RESEARCH METHODOLOGY}

\subsection{The Data Set}

The Enterprise Surveys collect data from key manufacturing and service sectors in every region of the world. For these analytical purposes, the study used primary data source from the 2015 World Bank Enterprise Surveys for Ethiopia (Ethiopia - Enterprise Survey 2015). The standardized Enterprise Survey questionnaire includes both objective and subjective questions referring to the business environment. Subjective variables are based on the perceptions of the surveyed firms regarding key factors that constrain their operations. The questionnaire, include among; others; in the areas of corruption ,crime, informality, regulatory and tax ,gender ,finance, infrastructure, innovation and technology, work place, firm characteristics and the biggest obstacle.

Ethiopia Enterprise Survey 2015 by that time was used three stage stratified random sampling. Three levels of stratification were industry establishment, size, and region. Industry stratification was designed in the way that follows: the population was stratified into four manufacturing industries, and three services sectors. Size stratification was defined as follows: small (5 to 19 employees), medium (20 to 99 employees), and large (more than 99employees). Whereas, regional stratification for the 2015 Ethiopia ES was done across six geographic regions: Addis Ababa and Dire Dawa city administrations, and Amhara, Oromia, SNNPR and Tigray regional states. The total number of sampled establishments contacted for the survey was $33 \%(1056)$ and as well the ES covers about 848 emprises nationwide. Finally the data set was cleaned by avoiding irregularities like I don't know answerers before putting into analysis.

\subsection{Methods of Data Analysis:}

In the study of intensity of informal or unregister competition among firms through descriptive and econometric methods of data analysis were used to assess the relationship between explanatory and dependent variables.

\subsubsection{Descriptive Statistics:}

Descriptive statistics were utilized to assess the characteristics of the sample Reponses that determined intensity of informal competition among firms in Ethiopia. This information was considered to augment the econometric analysis results. The descriptive analysis include among others, tools such as minimum, maximum, mean, percentage, standard deviation, frequency distribution

\subsubsection{Econometric Model}

The study employed binary probit regression model to study the intensity of informal competition among firms in Ethiopia.

$\mathrm{Y} i=ß \mathrm{X}^{\prime}+\mathrm{U}$ Where, $\mathrm{Yi}$ is dependent dummy variable reflecting the probability of competition of firms against informal firms. It takes the value of one for establishment compete against unregister firms and the value of zero otherwise. $X$ is a vector of explanatory variables that determines the intensity of informal competition, $\beta$ is a vector of unknown parameters to be estimated from the probit model.

\section{Definitions of Explanatory Variables}

Access finance - Limited access to financial services is one of the main constraints for informal firms (Morrisson 1995). The study used a measure of the utilization of commercial lines of credit or a loan from a financial institution as a way to evaluate the level of access to finance that firms have.. Here is created a binary variable where a value of one (1) indicates a firm access to credit and zero otherwise.

Exporter-For reasons of competitiveness, scale, technology, access to markets, access to credit, uncertain legal status, fixed costs of exporting, etc., informal firms are neither able nor willing to compete in export markets (González and Lamanna.2007). For this reason, the study included a dummy variable, where the value of one (1) represents direct exporter and zero (0) otherwise

Tax rate- the ES refers to the tax that a company must pay or withhold in a given year. It measures the administrative burden in paying taxes. Taxes are measured at all levels of government obstacle to the current operations of the establishment. Variable is normalized to a zero to one where one (1) indicates the highest tax rate of obstacles (severe obstacles and major obstacles) and zero otherwise.(Source: Doing business 2006, Creating Available: www.doing:www.doing business .org)

Size of firm-used in log of number of Permanent full-time employees in the firm Age of firms is calculated by subtracting 2014 from year of establishment began operations

Sex of the top manager- it is a control variable and assign 1 for female and zero for male 
Regulated by tax officials-refers whether establishment in last year, was visited or inspected by tax officials or required to meet with them. Assign 1 for yes response and zero for no

Corruption- refers the degree at which corruption is being an obstacle to the current operation of the establishment. Variable is normalized to a zero to one where one (1) indicates highest corruption and (0) otherwise.

Obstacles to accessing finance - refers the extent at which access to finance is being an obstacle to the current operations of the establishment. Variable is normalized to zero to one where one (1) indicates the highest obstacles for accessing finance and zero otherwise.

New product refers to whether the establishment introduced new or significantly improved products or services in the last three years. New product development is more likely when firms perceive greater obstacles from informal competition McCann and Bahl (2017).Yes for 1 and zero for No.

\subsection{Model Specification}

In this research, the relation between unemployment rate and the explanatory variable time was used simple time series regression model. Before employing this technique, the researcher had checked the relation between dependent and independent variables were graphically linear.

\section{RESULTS AND DISCUSSION}

\subsection{Descriptive analysis}

Descriptive statistics such as mean, minimum and maximum values range and standard deviations were used to describe the socio -economic characteristics of the sample Reponses that determined intensity of informal competition among firms in Ethiopia

Table1. Summary of factors characteristics

\begin{tabular}{|l|c|c|c|c|c|}
\hline Variables & $\mathrm{N}$ & Mean & Std. Dev & Min & Max \\
\hline Size of firms & 512 & 94.40385 & 374.9571 & 1 & 7600 \\
\hline $\begin{array}{l}\text { Sex of the top manager } \\
\text { Female (9\%) } \\
\text { Male ((91\%) }\end{array}$ & 512 & .0885478 & .2842578 & 0 & 1 \\
\hline Age of firms in years & 510 & 13.50885 & 12.85561 & 0 & 89 \\
\hline Experience of top manager in years & 512 & 15.79682 & 10.71342 & 1 & 60 \\
\hline $\begin{array}{l}\text { Percentage of firms direct export their sales (\%) } \\
\text { Direct export (9.7\%) } \\
\text { Indirect export (90.3\%) }\end{array}$ & 512 & 5.809113 & 20.76637 & 1 & 100 \\
\hline $\begin{array}{l}\text { Percentage firms inspected by tax officials last year } \\
\text { Yes (57.6\%) } \\
\text { No (42.4\%) }\end{array}$ & 512 & 1.423645 & .4944401 & 1 & 2 \\
\hline No .of times the firm inspected by tax officials & & & & \\
\hline Source: ES sy & 5.178112 & 17.29779 & 1 & 300 \\
\hline
\end{tabular}

Source: ES survey, 2014

Out of the total sampled firms, female top manager accounts for $9 \%$ while the rest $91 \%$ are males. The sampled establishment on average obtains their sale directly from export is about $9.7 \%$.The study indicated that the average size of firm is 94 employees with standard deviation of 374.957.The maximum is 7600 employees while the minimum is 1 .The average age of the sampled establishment is about 13.5 years with maximum of 89 years and minimum of 0 years with standard deviation 12.40 . The average experience of top manager is 16 years with standard deviation of 10.7134. Likewise, percentage of firms those are inspected and visited by tax officials last year was about $57.6 \%$, on average they are inspected 5 times a year.

\subsection{Econometrics Analysis}

In order to compute intensity of informal competition, binary probit model was employed. The model had a Log pseudo likelihood of (-313.81816) after third iteration and the Wald chi2 test statistics with 10 degree of freedom $=51.97$. Prob $>$ chi $2=0.0000$ revealed that the independent variables included in the model are adequately estimated (i.e., the model is adequate). In addition to this, goodness-of-fit test was carried out to examine whether determining factors of informal competition estimated probability is fit to this type of regression or not, The result shows that the pearson chi2(496) $=510.22$ and Prob $>$ chi $^{2}=0.3284$. As indicated by the goodness-offit (gof) tests after probit, the null that the model is fittest is not rejected at all levels of significant in the model, suggesting that the model is fit for probit model. 
Table2. Factors affecting informal competition

\begin{tabular}{|l|l|l|l|l|}
\hline Variables & Coefficients & Robust SE & $\mathrm{P}>\mid \mathrm{t}$ & Marginal effects \\
\hline Degree of obstacle to access finance & $.3507068^{* * *}$ & .127184 & 0.006 &. .1358043 \\
\hline Exporter & -.3194113 & .2061 & 0.121 & -.1163837 \\
\hline Tax rate & $2765964^{*}$ & .147023 & 0.060 & .1076491 \\
\hline Size of firms & $-.1784512^{* * *}$ & .046435 & 0.000 & -.0681911 \\
\hline Sex of the top manager & .136318 & .2187715 & 0.539 & .0511053 \\
\hline Tax rule enforcement & $.2609864 * *$ & .120426 & 0.030 & .0987957 \\
\hline Access to finance & .0149718 & .1264851 & 0.998 & .0057198 \\
\hline Degree of corruption & $.2717678^{* *}$ & .1373332 & 0.048 & .1055688 \\
\hline Age of firms & .019107 & .0747143 & 0.798 & .0073013 \\
\hline Experience of top manager & $0160833^{* * *}$ & .005939 & 0.007 & .0061459 \\
\hline Cons. & -.4777195 & .3170238 & 0.637 & - \\
\hline
\end{tabular}

Note: Number of observations 510; Waldchi2 (10) 51.97; Prob>chi2 0.0000; Log pseudo likelihood -313.81816 $* * *$ Significant at $1 \%, * *$ at $5 \%$ and $*$ at $10 \%$

By using the estimated parameters of the linear probability model, and asking whether the establishment compete against unregistered firms or not, the study found that the probability of firms those are competing against unregistered or informal firms are about $38.5 \%$.

The result of the probit model analysis indicated that firm size is significantly and negatively related with firms those are competing against informal firms at $1 \%$ level of significant. The study revealed that firm size negatively influence completion against informal firms as compared to formal firms. A World Bank study on informality in Latin America points out that "formality rises rapidly with firm size and productivity" (pg. 135; Perry et al, 2007).As before, the study argued that firms that are less productive, therefore tending to be more like informal firms, face informal competition more directly than more productive formal firms .The marginal effect result showed that a unit increase in permanent workers in an establishment results in a $0.00068 \%$ decrease in the intensity of informal competition as compared to the formal one (i.e., saving from informality) while keeping other variables constant.

Tax rate found positively and significantly influence intensity of informal competition among firms. The result of the probit model indicates that intensity of competition against informal firms is increasing as the prevalence of tax rate impediment to the business environment increases. The plausible reason could be a higher tax rate forces the formal firms to be informal and informal firms remains as informal. In Doing Business indicators tax rate refers to the tax that a company must pay or withhold in a given year. It also measures the administrative burden in paying taxes (González and Lamanna, 2007)).Moreover, from marginal effects, being highest tax rate prevalence, citrus paribus, increase intensity of informal competition by $10.8 \%$ as compared to firms that perceived it not highest obstacles and or no obstacles. .

Corruption found positively and significantly influences intensity of informal competition at $10 \%$ level of significant. The result of the probit model indicated that intensity of competition against informal firms is increasing as obstacles of corruption to the business increases. The plausible reason could be a highest corruption drive formal firms to be informal and informal firm's remains as informal. According to Iriyama, Kishore and Talukdar (2016), in their study argued that one way formal firms can respond to informal competition by engaging in corrupt activities such as payoffs to regulatory officials in an attempt to achieve parity on speed and low cost .From marginal effects, highest corruption prevalence, citrus paribus, increase intensity of informal competition by $10.6 \%$ as compared to firms those perceived it not highest obstacles.. .

The study also found that access to Finance is an obstacle to the current operations of an establishment, significantly influence intensity of informal competition. The result of the probit model showed that intensity of competition against informal firms increases as an obstacle of accessing finance increases. According to Morrisson (1995), found that limited access to financial services is one of the main constraints for informal firms to remain informal. The plausible reason could be a higher obstacle for accessing finance drives the formal firms to be informal and informal firms leftovers as informal .Moreover, from marginal effects, highest obstacle of accessing finance, all other variables keep constant, increase intensity of informal competition by $13.6 \%$ as compared to firms those are perceiving it not highest obstacles .

Likewise, by using the estimated parameters of the linear probability model, and taking tax official's regulation and inspection of an establishment over the last year as an example of enforcing tax regulation, intensity of informal competition is $9.9 \%$ higher for firms who are regulated and inspected by tax officials over the last year as compared to firms those are not visited. In practical terms, firms those are visited and inspected by tax officials regularly, they get and learn to do their business formally in accordance with the rules and regulation of the tax code, and firms are saving from informality. However, in this case, in a country like Ethiopia, informality does not seem to decrease because there is no a well rigorous system to implement regular 
inspection. The higher the regulatory burdens of being formal, the higher are savings from informality. However, the cost-benefit calculation affects the size of the informal sector as higher savings from being informal draws more firms to informality, resulting in a bigger informal sector (Djankov et al 2002, Schneider 2000). Informal firms are most common in countries where the legal and regulatory systems are such that it is costly and procedurally challenging to register firms and operate in the realm of law (Godfrey, 2011).

Experience of the top manager also found to be positively and significantly influence intensity of informal competition. The result of the probit model indicates that intensity of informal competition is increasing as the experience of top manager increases. The marginal effect result exhibited that a one-year increase in experience of top managers led to an increase intensity of informal competition by $0.6 \%$ as compared to formal ones..

\section{CONCLUSIONS}

The study hypothesized that firm size is negatively and significantly related with prevalence of completion against informal firms. The study found that firm size is negatively related with the occurrence of informal competition. Increasing firm size obliged firms to utilize their maximum production capacity and that could serve them to decrease price, and this in turn provide an incentive to overcome intensity of informal competition. Whereas ,the study also hypothesized that experience of top manager is negatively and significantly affecting intensity of informal competition. However, the result revealed that experience of top manager is adversely affecting informal competition .That is to say, experience of top managers do not save the firm from informal competition ...

Likewise, inspection and meeting with tax official ,for instance 6 times in a year could not seem to contribute for reducing the intensity of informal competition. The plausible reason could be, in developing country like Ethiopia, there is no a full-fledged system that could help to monitor informality as a whole .The study also found that male headed firms are 10 times greater as compared to female headed firms .This implies that women's are not yet empowered in the sectors under study and it requires due attention by the government .

Similarly, average age of firms and experience of top manager are so adequate to obtain their sale directly from export .However, the prevalence average of firms those are engaging in this activities are about $9.7 \%$. This could be explained by different reasons in literatures; however, it requires deep study for further researchers. Finally, the study found that Prevalence of highest tax rate, corruption, and obstacle of accessing finance are found to be the major concerns that are aggravating the intensity of informal competition in Ethiopia.

\section{Reference}

Bruton, G. D., Ireland, R. D., \& Ketchen Jr, D. J. (2012). Toward a research agenda on the informal economy. Academy of Management Perspectives, 26(3), 1-11.

Djankov, S., McLiesh, C., \& Ramalho, R. M. (2006). Regulation and growth. Economics letters, 92(3), 395-401.

Djankov, S., R. La Porta, F. Lopez-de-Silanes, and A. Shleifer (2003), "Courts" Quarterly Journal of Economics, 18(2): 453-517.

Djankov, S., R. La Porta, F. Lopez-de-Silanes, and A. Shleifer (2002), “The regulation of entry," Quarterly Journal of Economics, 117(1): 1-37.

El de Soto H. 2000. The Mystery of Capital. Basic Books: New York

Friesen, J., \& Wacker, K. (2013). Do financially constrained firms suffer from more intense competition by the informal sector? Firm-level evidence from the world bank enterprise surveys (No. 139). Courant Research Centre: Poverty, Equity and Growth-Discussion Papers.

Godfrey PC. 2011. Toward a theory of the informal economy. Academy of Management Annals 5(1): 231-277

González, A. S., \& Lamanna, F. (2007). Who fears competition from informal firms? Evidence from Latin America. The World Bank.

-Hamidi, F. (2011). How do women entrepreneurs perform. Empirical Evidence.

Hendy, R., \& Zaki, C. (2013). On informality and productivity of micro and small enterprises: Evidence from MENA countries. International Journal of Entrepreneurship and Small Business, 19(4), 438-470.

Iriyama A, Kishore R, Talukdar D. 2016. Playing dirty or building capability? Corruption and HR training as competitive actions to threats from informal and foreign firm rivals. Strategic Management Journal 37(10): 2152-2173.

Johnson S, Kaufmann D, McMillan J, Woodruff C. 2000. Why do firms hide? Bribes and unofficial activity after communism. Journal of Public Economics 76(3): 495-520

Johnson, S., D. Kaufmann, J. McMillan, and C. Woodruff (2000), "Why do firms hide?: Bribes and unofficial activity after communism", Journal of Public Economics, 76 (3):495-520.

McCann, B. T., \& Bahl, M. (2017). The influence of competition from informal firms on new product development. Strategic Management Journal, 38(7), 1518-1535.

McKenzie, D., \& Sakho, Y. S. (2010). Does it pay firms to register for taxes? The impact of formality on firm 
profitability. Journal of Development Economics, 91(1), 15-24.

McKenzie, D., Seynabou Sakho, Y., 2010. Does it pay firms to register for taxes? The impact of formality on firm profitability. J. Dev. Econ. 91 (1), 15-24

Mendi, P., \& Mudida, R. (2018). The effect on innovation of beginning informal: Empirical evidence from Kenya. Technological Forecasting and Social Change, 131, 326-335.

Morrisson, C. (1995), "What institutional framework for the informal sector?", OECD, Policy Brief No. 10.

Nichter S, Goldmark L. 2009. Small firm growth in developing countries. World Development 37(9): 14531464.

Perry, G.E., W.F. Maloney, O.S. Arias, P. Fajnzylber, A.D. Mason, and J. SaadvedraChanduvi (2007), "Informality: Exit and exclusion", World Bank Latin America and Caribbean Studies.

Radjou, N., Prabhu, J., Ahuja, S., 2012. Jugaad Innovation: Think Frugal, Be Flexible, Generate Breakthrough Growth. Jossey-Bass business \& management series, Wiley

riyama A, Kishore R, Talukdar D. 2016. Playing dirty or building capability? Corruption and HR training as competitive actions to threats from informal and foreign firm rivals. Strategic Management Journal 37(10): 2152-2173.

Schneider F, Enste DH. 2002. The Shadow Economy: An International Survey. Cambridge University Press: New York.

Schneider, F., \& Enste, D. (2002). Hiding in the shadows: the growth of the underground economy (Vol. 30). International Monetary Fund.De Soto, H. (1989), The Other Path: The Invisible Revolution in the Third World. Harper Row, New York

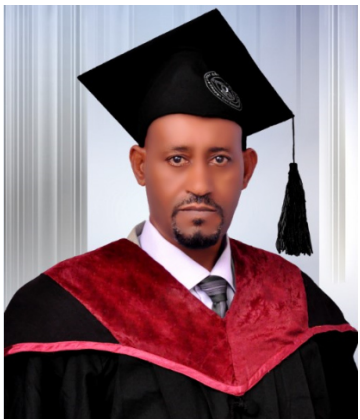

Abiy Serawitu Kassaye

Senior consultant at Dire Dawa Management and Kaizen Instit

(PhD Candidate)

E-mail:askabiy@gmail.com 